\title{
Identification of Irradiated Potatoes by Impedance Measurements
}

\author{
Toru Hayashi, Mutsuo Iwamoto and Koji Kawashima
}

National Food Research Institute, Ministry of Agriculture, Forestry and Fisheries, 2-1-2, Kannondai, Yatabe-machi, Tsukuba-gun, Ibaraki 305, Japan

Received July 30, 1981

\begin{abstract}
Measuring the impedance was found to be a highly reliable and practical technique for identifying irradiated potatoes. Impedance was measured by puncturing a potato tuber with a steel electrode and passing a $3 \sim 5 \mathrm{~mA}$ alternating current through it. Three parameters were determined: $Z_{0} / Z_{180}$ (impedance ratio at $5 \mathrm{kHz}, 0$ to 180 seconds after puncturing), $Z_{50 \mathrm{k}} / Z_{0.5 \mathrm{k}}$ (impedance ratio at $50 \mathrm{kHz}$ to $0.5 \mathrm{kHz}$ ) and $Z_{50 \mathrm{k}} / Z_{5 \mathrm{k}}$ (impedance ratio at $50 \mathrm{kHz}$ to $5 \mathrm{kHz}$ ). Among these, parameter $Z_{50 \mathrm{k}} / Z_{5 \mathrm{k}}$ was the most favourable index. The technique allowed not only differentiation between unirradiated and irradiated potatoes but an estimation of the irradiation dose for up to six months after irradiation, independent of the potato storage condition.
\end{abstract}

Irradiated potatoes are accepted unconditionally by the international authorities ${ }^{1 \sim 2)}$ (IAEA, WHO and FAO) and permitted in various countries ${ }^{3)}$ in the world. In Japan commercial potato irradiation with $\mathrm{Co}-60$ on a larger scale has been performed in order to inhibit sprouting since 1973. Every year around $20000 \mathrm{t}$ of potatoes (Danshaku) are irradiated with a dose of 7 to $15 \mathrm{krad}$. Although the wholesomeness of irradiated potatoes has already been confirmed, ${ }^{1,2)}$ some consumers are against them and are interested in a reliable method to differentiate between unirradiated potatoes and irradiated ones. The technique to identify irradiated potatoes should be dependent upon the irradiation dose but not on other conditions for storage, growth etc. Such a technique is also required at an irradiation plant to avoid re-irradiation.

A reliable technique to identify irradiated potatoes has not so far been established, although several methods have been reported. ${ }^{4}$ 14) Most of these dealt with enzyme activities, ${ }^{7,9)}$ or with the amount of potato components $^{4,8}$ ) like carbohydrates, amino acids, vitamins and chlorogenic acid, which all changed during storage and were influenced by the storage and growth conditions and by the potato varieties.

The technique of measuring the electrical conductivity of potatoes has been report$\mathrm{ed}^{10 \sim 14)}$ to be promising for this identification. The conductivity is measured by puncturing a potato tuber with an electrode and passing alternating current through it. The process is quite simple, takes only 3 minutes and does not require a trained operater. Irradiation lowers the electrical conductivity of potatoes measured immediately after puncturing with an electrode. After puncturing the conductivity continues to decrease for a few minutes depending on the irradiation dose. These effects are independent of the type of irradiation used for sprout inhibition. Scherz ${ }^{10 \sim 12)}$ measured the electrical conductivity at $50 \mathrm{~Hz}$ and concluded that $\Lambda_{0}$ (electrical conductivity immediately after puncturing) changed depending on the potato sample and $\Lambda_{30}-\Lambda_{180}$ (or $\Lambda_{0}-\Lambda_{180}$ ) was a better identification parameter, where $\Lambda_{t}$ is the electrical conductivity of potatoes $t$ seconds after puncturing. Hayashi and Ehlermann ${ }^{14)}$ improved the technique; an alternating current frequency of $5 \mathrm{kHz}$ and a steel electrode gave the best results and the parameter of $\Lambda_{180} / \Lambda_{30}$ (or $\Lambda_{180} /$ $\Lambda_{0}$ ) was best suited for the identification. 
Despite this improvement, the conductivity measurement did not result in a reliable identification, because the parameter of $\Lambda_{180} / \Lambda_{30}$ was still unstable during storage after irradiation.

Impedance has been reported ${ }^{15 \sim 19)}$ to be dependent on the physiological conditions of plants, and winter hardiness of tree seedlings, ${ }^{15,18)}$ virus infection of plants ${ }^{17)}$ and the effectiveness of herbicides ${ }^{16)}$ have all been investigated by impedance measurement. In these investigations a ratio of impedance at low frequency to that at high frequency proved of higher significance than an impedance value itself.

In this report, the measurement conditions of impedance were investigated. Several identification parameters of impedances at low frequency, an impedance ratio at 0 to $180 \mathrm{sec}$ after puncturing with the electrode and impedance ratios of low frequency to high frequency were compared using a large number of potatoes.

\section{MATERIALS AND METHODS}

Potato. Unless otherwise stated, the potato variety of Danshaku was used for this study, since potatoes of this variety are commercially irradiated in Japan. The potatoes were obtained from Shihoro Agricultural Co-operative, where commercial irradiation of potatoes is conducted. Potatoes of the variety May-Queen were obtained from a local market in Tsukuba, Ibaraki-ken.

Irradiation. Potatoes were irradiated with a dose of 0 to

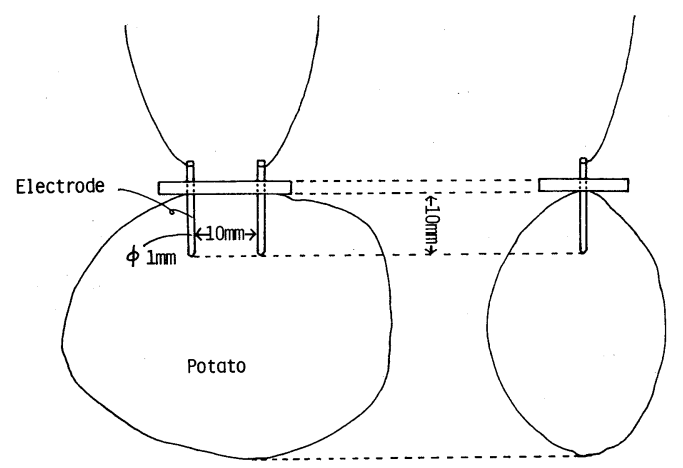

FIG. 1. Diagram of the Steel Electrodes Used in Measuring the Impedance of a Potato Tuber.
100 krad using a Gamma Cell 220 (Canada AEC, Co-60, $288 \mathrm{krad} / \mathrm{hr}$ ). The accuracy of the irradiation dose rate was within $\pm 15 \%$. After irradiation, the potatoes were stored at 5 or $15^{\circ} \mathrm{C}$ in a dark room.

Impedance measurement. Prior to the experiments, the potatoes were adjusted to $20^{\circ} \mathrm{C}$ and the electrical measurements were carried out at that temperature with the aid of stainless-steel electrodes; $1 \mathrm{~mm}$ diameter, $1 \mathrm{~cm}$ long and $1 \mathrm{~cm}$ apart (Fig. 1). The impedance was determined by puncturing a potato tuber with the electrodes which were connected to a Vector Impedance Meter 4800 A (Hewlett Packard Ltd.), and expressed as follows. $Z_{x}$, impedance measured $x$ sec after puncturing; $Z_{y \mathbf{k}}$, impedance at $y \mathrm{kHz}$ measured immediately after puncturing.

\section{RESULTS AND DISCUSSION}

\section{Impedance at various frequencies}

Potatoes were irradiated with a dose of 0 , 15 , or $100 \mathrm{krad}$ and stored at $15^{\circ} \mathrm{C}$ for 1 week. Their impedance was measured at $20^{\circ} \mathrm{C}$ at various frequencies of alternating current. Each point in Fig. 2 is an average of 10 measurements in 5 potatoes measured immediately after puncturing with the electrodes. In the low frequency range the impedances were different depending on the irradiation dose, but at higher frequencies this difference could not be observed. These results suggested the suitability of impedance measurement at low frequency as a tool for identification. But Scherz ${ }^{10 \sim 12)}$ reported that the electrical conductivity at $50 \mathrm{~Hz}$ was rather scattered and would not be a stable parameter.

As described above, the ratio of impedance at low frequency to that at high frequency has

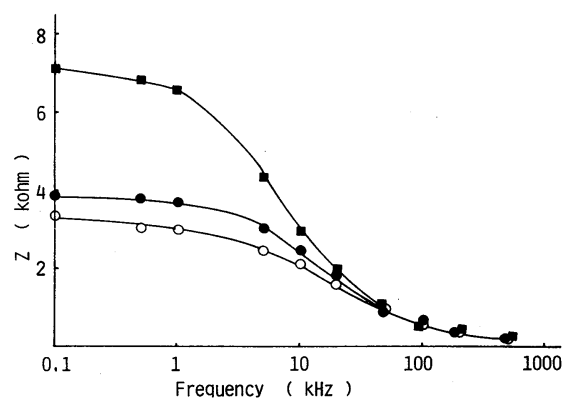

FIG. 2. Impedance of Potatoes at Various Frequencies of Alternating Current.

O, $0 \mathrm{krad}$;, $15 \mathrm{krad}$; $100 \mathrm{krad}$. 
been recommended for use as a parameter for the diagnosis of plants, ${ }^{15 \sim 19)}$ and this seemed to be worth trying as a parameter for the identification of irradiated potatoes. In this study the ratio of impedance at $50 \mathrm{kHz}$ to that at $0.5 \mathrm{kHz}\left(Z_{50 \mathrm{k}} / Z_{0.5 \mathrm{k}}\right)$ and the ratio of impedance at $50 \mathrm{kHz}$ to that at $5 \mathrm{kHz}\left(Z_{50 \mathrm{k}} / Z_{5 \mathrm{k}}\right)$ were used as identification parameters.

\section{Changes in impedance after puncturing with the electrodes}

Potatoes were irradiated with a dose of 0,15 or $100 \mathrm{krad}$ and stored at $15^{\circ} \mathrm{C}$ for 1 week. Their impedence at $5 \mathrm{kHz}$ was measured at $20^{\circ} \mathrm{C}$. The impedance measurement was done at intervals after puncturing the potato sample with the electrodes by keeping them in the tuber. Each point in Fig. 3 is an average of 10 measurements in 5 potatoes. The impedance of unirradiated potatoes kept increasing with the time after puncturing, whereas at $15 \mathrm{krad}$ the impedance was almost constant and at $100 \mathrm{krad}$ it kept decreasing. These results sug-

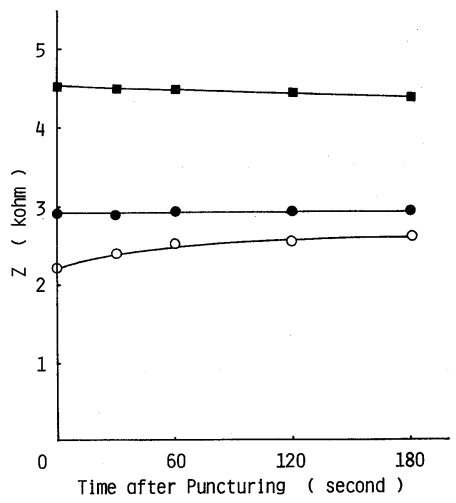

FIG. 3. Impedance Change at $5 \mathrm{kHz}$ after Puncturing a Potato Tuber.

O, $0 \mathrm{krad}$;, $15 \mathrm{krad} ; \boldsymbol{\square}, 100 \mathrm{krad}$. gested that the impedance change after puncturing with the electrodes would be promising for the identification of irradiated potatoes. Although the applicability of $\Lambda_{180} / \Lambda_{0}$ has been already investigated, ${ }^{14)}$ the ratio of the impedance 0 second to that 180 seconds after puncturing $\left(Z_{0} / Z_{180}\right)$ seemed to be a better parameter to compare with the parameters of $Z_{50 \mathrm{k}} /$ $Z_{0.5 \mathrm{k}}$ and $Z_{50} / Z_{5 \mathrm{k}}$.

\section{Relationship between the identification param-} eter, $Z_{0} / Z_{180}$, and the frequency of alternating current

Potatoes were irradiated with a dose of 0 to $100 \mathrm{krad}$ and stored at $15^{\circ} \mathrm{C}$ for 1 week. Their impedance was measured at $20^{\circ} \mathrm{C}$ at various frequencies of alternating current to determine $Z_{0} / Z_{180}$. As shown in Fig. $4, Z_{0} / Z_{180}$ increased as the irradiation dose increased in the frequency range of $50 \mathrm{~Hz}$ to $10 \mathrm{kHz}$, but this effect was not observed at $50 \mathrm{kHz}$, where the mean values and the standard deviations were determined with 6 measurements in 6 potatoes. In order to establish the best frequency for the

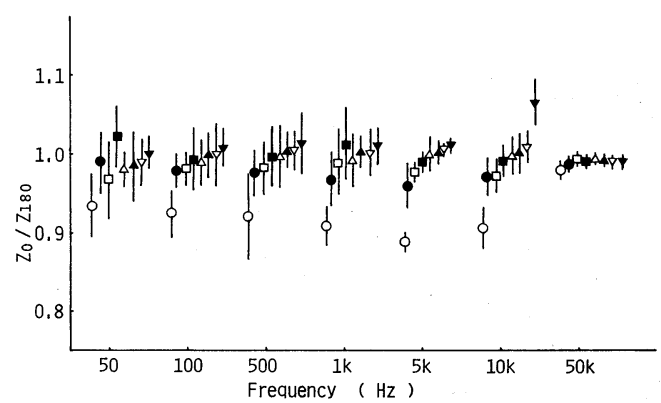

FIG. 4. Relationship between the Identification Parameter, $Z_{0} / Z_{180}$, at $20^{\circ} \mathrm{C}$ and the Frequency of Alternating Current.

$\bigcirc, 0 \mathrm{krad} ; \bigcirc, 5 \mathrm{krad} ; \square, 10 \mathrm{krad} ; \mathbf{\square}, 15 \mathrm{krad} ; \triangle, 20 \mathrm{krad}$;

$\mathbf{\Delta}, 30 \mathrm{krad} ; \nabla, 50 \mathrm{krad} ; \boldsymbol{\nabla}, 100 \mathrm{krad}$.

Table I. Variance Ratio $\left(V_{R} / V_{e}=F\right)$ of Identification Parameter, $Z_{0} / Z_{180}$, Determined AT VARIOUS FREQUENCIES OF Alternating CurRent

\begin{tabular}{cccccccc}
\hline $\begin{array}{c}\text { Frequency } \\
(\mathrm{Hz})\end{array}$ & 50 & 100 & 500 & $1 \mathrm{k}$ & $5 \mathrm{k}$ & $10 \mathrm{k}$ & $50 \mathrm{k}$ \\
\hline$F$ & 8.38 & 18.48 & 8.44 & $\begin{array}{l}11.55 \\
48\end{array}$ & $\begin{array}{l}60.01 \\
48\end{array}$ & $\begin{array}{l}24.73 \\
48\end{array}$ & $\begin{array}{c}1.27 \\
48\end{array}$ \\
\hline
\end{tabular}


parameter of $Z_{0} / Z_{180}$, the variance ratio $\left(V_{R} /\right.$ $V_{e}=F$ ) of the results was calculated (Table I). The frequency of $5 \mathrm{kHz}$ produced the highest $F$-value, which indicated that this frequency was best suited for identification when the parameter of $Z_{0} / Z_{180}$ was used. This result agreed with that of the previous paper, ${ }^{14)}$ where $\Lambda_{180} / \Lambda_{0}$ was used as a parameter and the best frequency of $5 \mathrm{kHz}$ was obtained from the results of 5 weeks' measurements.

\section{Measuring temperature}

Potatoes of Danshaku and May-Queen were irradiated with a dose of 0,20 or $100 \mathrm{krad}$ and stored at $15^{\circ} \mathrm{C}$ for 1 week. Their impedance was measured at various temperatures. The parameters of $Z_{0} / Z_{180}, Z_{50 \mathrm{k}} / Z_{0.5 \mathrm{k}}$ and $Z_{50 \mathrm{k}} /$ $Z_{5 \mathrm{k}}$ were determined at each temperature. At $5^{\circ} \mathrm{C}$ the differentiation between unirradiated potatoes and irradiated ones was possible but the estimation of the irradiation dose was impossible as shown in Figs. 5 to 7, where the mean values and the standard deviations were determined with 10 measurements in 5 potatoes. In the temperature range of 20 to $35^{\circ} \mathrm{C}$
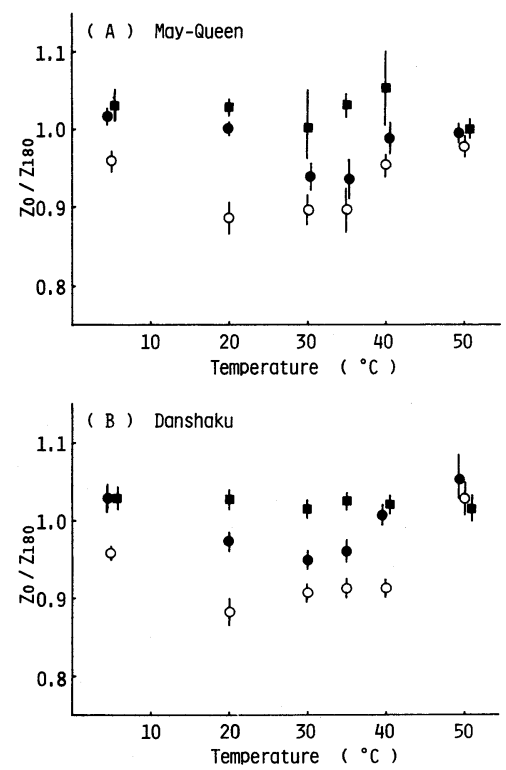

FIG. 5. Relationship between the Identification Parameter, $Z_{0} / Z_{180}$, at $5 \mathrm{kHz}$ and the Measuring Temperature.

○, $0 \mathrm{krad}$; , $20 \mathrm{krad} ; \mathbf{\square}, 100 \mathrm{krad}$. each parameter depended on the irradiation dose, which indicated the possibility of estimation of the irradiation dose as well as differentiation between unirradiated and irradiated potatoes. Higher temperatures, however, resulted in poorer identification. The
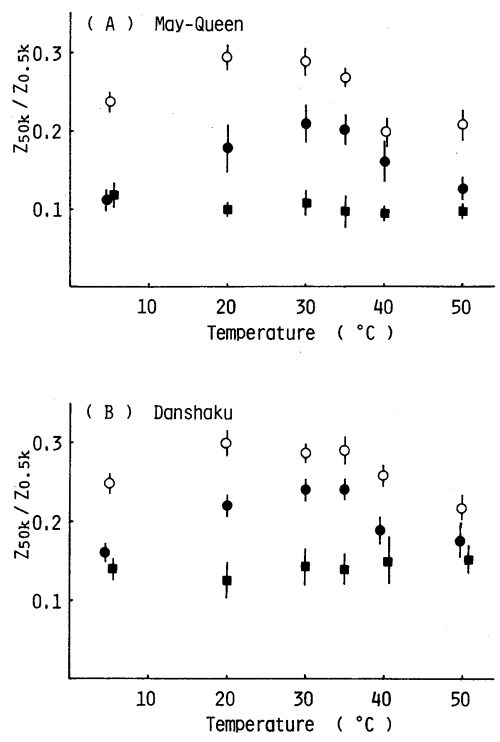

FIG. 6. Relationship between the Identification Parameter, $Z_{50 \mathrm{k}} / Z_{0.5 \mathrm{k}}$, and the Measuring Temperature. $\bigcirc, 0 \mathrm{krad} ; 0,20 \mathrm{krad} ; \mathbf{\square}, 100 \mathrm{krad}$.
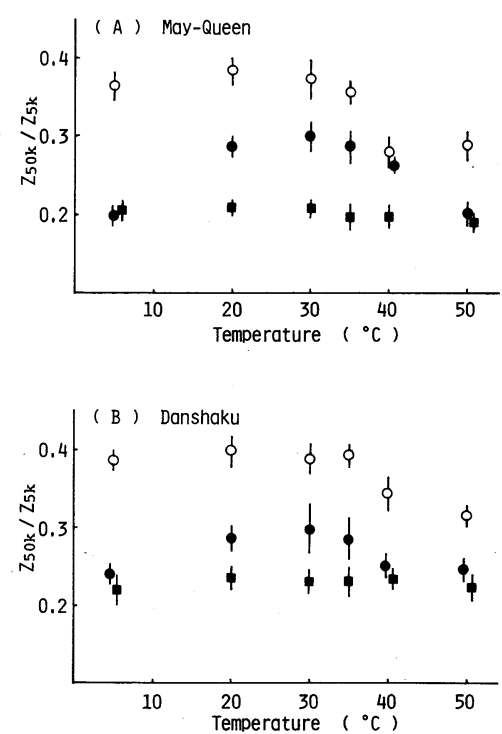

FIG. 7. Relationship between the Identification Parameter, $Z_{50 \mathrm{k}} / Z_{5 \mathrm{k}}$, and the Measuring Temperature.

○, $0 \mathrm{krad}$;, $20 \mathrm{krad}$; $\square, 100 \mathrm{krad}$. 
Table II. Variance Ratio $\left(V_{R} / V_{e}=F\right)$ of Identification Parameters Determined at Various Temperatures for Potatoes Irradiated WITH A DOSE OF 0, 20 OR $100 \mathrm{krad}$

(A) May-Queen

\begin{tabular}{|c|c|c|c|c|c|c|}
\hline \multirow{2}{*}{ Parameter } & \multicolumn{6}{|c|}{ Temp. $\left({ }^{\circ} \mathrm{C}\right)$} \\
\hline & 5 & 20 & 30 & 35 & 40 & 50 \\
\hline$Z_{0.5 \mathrm{k}}$ & 58.6 & 198.3 & 174.2 & 97.6 & 161.4 & 154.3 \\
\hline$Z_{50 \mathrm{k}} / Z_{0.5 \mathrm{k}}$ & 127.6 & 202.6 & 196.3 & 175.7 & 86.8 & 140.9 \\
\hline$Z_{5 \mathrm{k}}$ & 49.5 & 79.9 & 113.8 & 93.9 & 71.9 & 94.1 \\
\hline$Z_{50 \mathrm{k}} / Z_{5 \mathrm{k}}$ & 203.1 & 368.5 & 185.5 & 209.0 & 43.0 & 260.1 \\
\hline$Z_{50 \mathrm{k}}$ & 4.5 & 7.6 & 4.5 & 0.4 & 3.5 & 3.1 \\
\hline$Z_{0} / Z_{180}$ & 52.0 & 285.1 & 49.8 & 81.9 & 20.6 & 10.5 \\
\hline
\end{tabular}

(B) Danshaku

\begin{tabular}{lrrrrrr}
\hline & \multicolumn{7}{c}{ Temp. $\left({ }^{\circ} \mathrm{C}\right)$} \\
\cline { 2 - 7 } Parameter & \multicolumn{1}{c}{5} & 20 & 30 & 35 & 40 & 50 \\
\hline$Z_{0.5 \mathrm{k}}$ & 75.5 & 91.5 & 139.5 & 55.4 & 33.2 & 21.9 \\
$Z_{50 \mathbf{k}} / Z_{0.5 \mathrm{k}}$ & 210.4 & 265.2 & 200.1 & 203.9 & 49.4 & 32.3 \\
$Z_{5 \mathbf{k}}$ & 94.9 & 75.0 & 104.4 & 76.4 & 20.1 & 36.2 \\
$Z_{50 \mathbf{k}} / Z_{5 \mathbf{k}}$ & 341.7 & 294.8 & 309.4 & 117.4 & 57.6 & 50.5 \\
$Z_{50 \mathbf{k}}$ & 3.1 & 5.1 & 20.6 & 1.6 & 11.3 & 1.6 \\
$Z_{0} / Z_{180}$ & 100.7 & 256.4 & 81.6 & 240.6 & 254.8 & 4.2 \\
\hline
\end{tabular}

variance ratio ( $F$-value) of the results was calculated to establish the best conditions for identification (Table II), where $Z_{50 \mathrm{k}}, Z_{5 \mathrm{k}}$ and $Z_{0.5 \mathrm{k}}$ were also subjected to calculation.

The normalized parameters of $Z_{50 \mathrm{k}} / Z_{0.5 \mathrm{k}}$ and $Z_{50 \mathrm{k}} / Z_{5 \mathrm{k}}$ produced higher $F$-values than $Z_{0.5 \mathrm{k}}, Z_{5 \mathrm{k}}$ and $Z_{50 \mathrm{k}}$, which indicated that the normalization might lead to better identification. These results proved the validity of using $Z_{50 \mathrm{k}} / Z_{0.5 \mathrm{k}}$ and $Z_{50 \mathrm{k}} / Z_{5 \mathrm{k}}$ instead of $Z_{0.5 \mathrm{k}}$ and $Z_{5 \mathrm{k}}$ (see the section "Impedance at various frequencies"). A measuring temperature of $20^{\circ} \mathrm{C}$ produced the highest $F$-values for $Z_{50 \mathrm{k}} /$ $Z_{0.5 \mathrm{k}}, Z_{50 \mathrm{k}} / Z_{5 \mathrm{k}}$ and $Z_{0} / Z_{180}$ with May-Queen. With Danshaku a measuring temperature of $20^{\circ} \mathrm{C}$ did not always produce the highest $F$ values for the parameters but did produce consistently high $F$-values. From these results a measuring temperature of $20^{\circ} \mathrm{C}$ was concluded to be best suited for the identification of irradiated potatoes.

\section{Identification during a long storage}

Potatoes of Danshaku were irradiated with a dose of 0 to $100 \mathrm{krad}$ and stored at $5^{\circ} \mathrm{C}$ or $15^{\circ} \mathrm{C}$ in a dark room. The impedance of the potatoes was measured at $20^{\circ} \mathrm{C}$ periodically for 6 months. The results were shown in Figs. 8 to 13 , where the mean values and the standard deviations were determined with 10 measurements in 5 potato tubers. When stored at $15^{\circ} \mathrm{C}$, the unirradiated potatoes started sprouting in 40 days (indicated with an arrow in Figs. 9, 11 and 13) and in the 4th month their sprouts were longer than $10 \mathrm{~cm}$, so the impedance measurement was ceased thereafter. Although the parameter of $Z_{0} / Z_{180}$ changed during storage, the parameters of $Z_{50 \mathrm{k}} / Z_{0.5 \mathrm{k}}$ and $Z_{50 \mathrm{k}} /$ $Z_{5 \mathrm{k}}$ stayed constant during storage after irradiation. The two parameters were dependent on the irradiation dose but independent of the storage temperature. The parameter of $Z_{50 \mathrm{k}} /$ $Z_{0.5 \mathrm{k}}$ scattered more than $Z_{50 \mathrm{k}} / Z_{5 \mathrm{k}}$, which was confirmed from the $F$-values in Table III. The mean values, standard deviations and $F$-values 


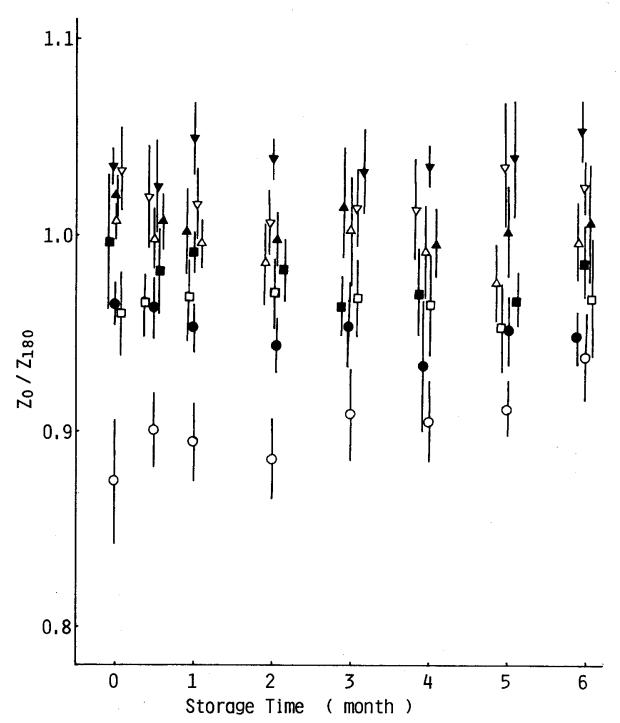

FIG. 8. Identification Parameter, $Z_{0} / Z_{180}$, at $5 \mathrm{kHz}$ for the Potatoes Stored at $5^{\circ} \mathrm{C}$.

$\bigcirc, 0 \mathrm{krad} ; \bigcirc, 5 \mathrm{krad} ; \square, 10 \mathrm{krad} ; \square, 15 \mathrm{krad} ; \triangle, 20 \mathrm{krad}$; A, $30 \mathrm{krad} ; \nabla, 50 \mathrm{krad} ; \nabla, 100 \mathrm{krad}$.

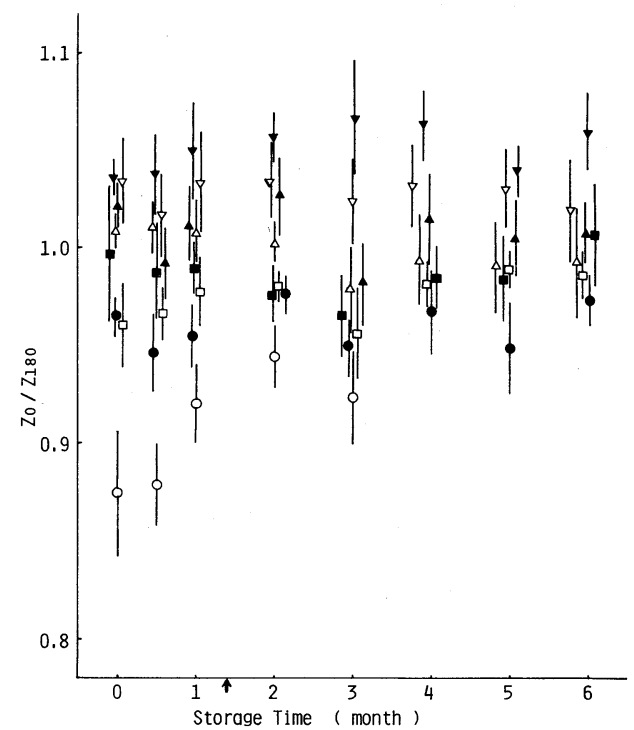

FIG. 9. Identification Parameter, $Z_{0} / Z_{180}$, at $5 \mathrm{kHz}$ for the Potatoes Stored at $15^{\circ} \mathrm{C}$.

$\bigcirc, 0 \mathrm{krad}$ ○, $5 \mathrm{krad}$; $\square, 10 \mathrm{krad} ; \square, 15 \mathrm{krad} ; \triangle, 20 \mathrm{krad}$; $\boldsymbol{\Delta}, 30 \mathrm{krad} ; \nabla, 50 \mathrm{krad} ; \boldsymbol{\nabla}, 100 \mathrm{krad}$.

in Table III were determined with all the data from 6 months' measurements.

The parameter of $Z_{50 \mathrm{k}} / Z_{5 \mathrm{k}}$ at $20^{\circ} \mathrm{C}$ was concluded to be the best index for the identifi-

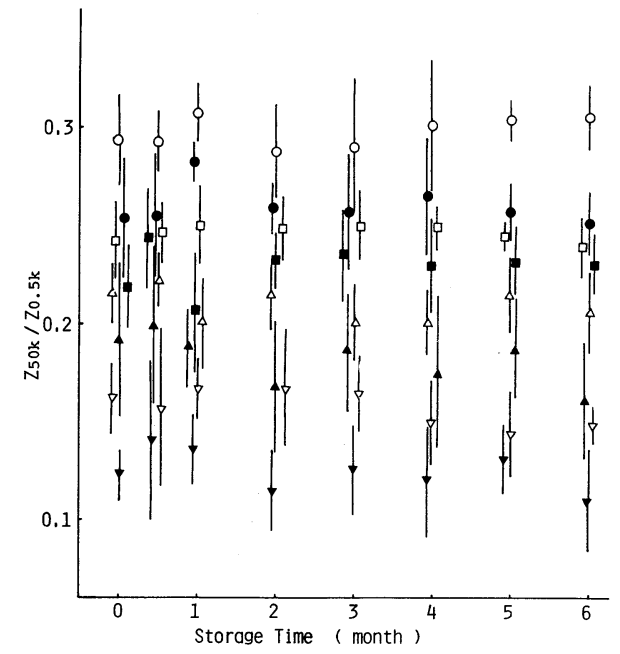

FIG. 10. Identification Parameter, $Z_{50 \mathrm{k}} / Z_{0.5 \mathrm{k}}$, for the Potatoes Stored at $5^{\circ} \mathrm{C}$.

$\bigcirc, 0 \mathrm{krad}, \bigcirc, 5 \mathrm{krad} ; \square, 10 \mathrm{krad}, \boldsymbol{\square}, 15 \mathrm{krad} ; \triangle, 20 \mathrm{krad}$,

$\boldsymbol{\Delta}, 30 \mathrm{krad}, \nabla, 50 \mathrm{krad}, \boldsymbol{\nabla}, 100 \mathrm{krad}$.

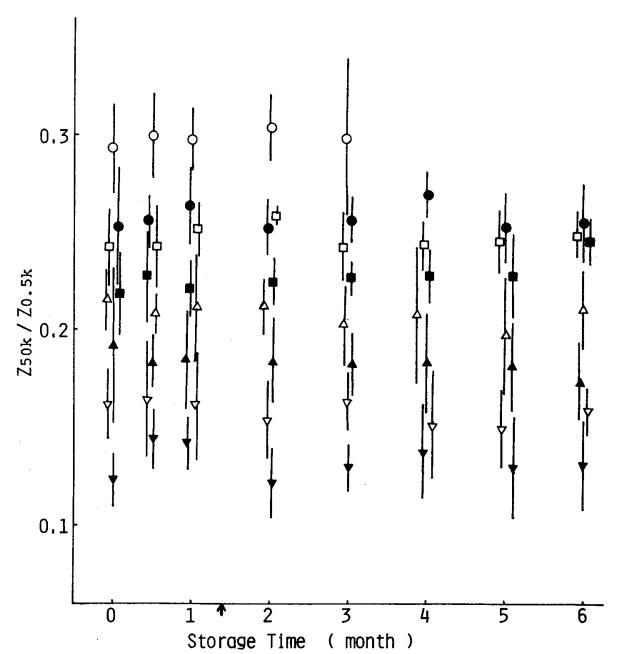

FIG. 11. Identification Parameter, $Z_{50 \mathrm{k}} / Z_{0.5 \mathrm{k}}$, for the Potatoes Stored at $15^{\circ} \mathrm{C}$.

$\bigcirc, 0 \mathrm{krad} ; \bigcirc, 5 \mathrm{krad} ; \square, 10 \mathrm{krad} ; \square, 15 \mathrm{krad} ; \triangle, 20 \mathrm{krad}$; $\Delta, 30 \mathrm{krad} ; \nabla, 50 \mathrm{krad}, \boldsymbol{\nabla}, 100 \mathrm{krad}$.

cation of irradiated potatoes; roughly speaking, unirradiated potatoes will give a value of 0.43 to 0.36 , potatoes irradiated with the legally admitted dose ( 7 to $15 \mathrm{krad}$ ) will give a value of 0.35 to 0.29 and potatoes irradiated with a dose exceeding the admitted level will give a value lower than 0.29 (Table III). These criteria were independent of storage tempera- 


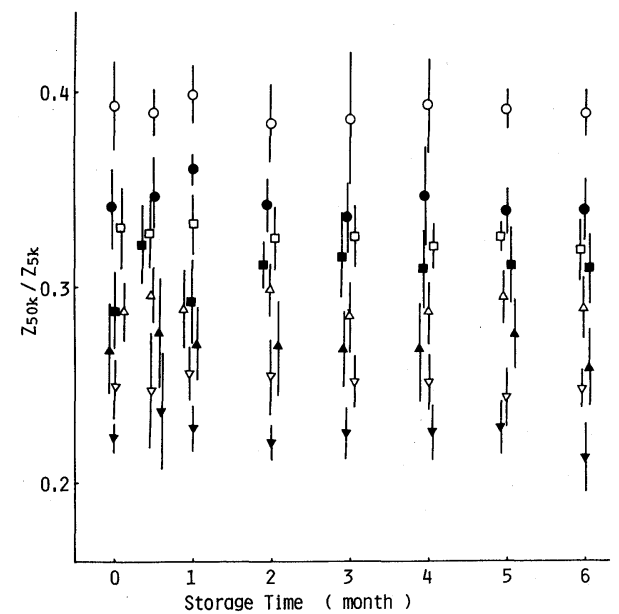

FIG. 12. Identification Parameter, $Z_{50 \mathrm{k}} / Z_{5 \mathrm{k}}$, for the Potatoes Stored at $5^{\circ} \mathrm{C}$.

$\bigcirc, 0 \mathrm{krad}$; , $5 \mathrm{krad} ; \square, 10 \mathrm{krad} ; \square, 15 \mathrm{krad} ; \triangle, 20 \mathrm{kard}$;

$\Delta, 30 \mathrm{krad} ; \nabla, 50 \mathrm{krad} ; \boldsymbol{\nabla}, 100 \mathrm{krad}$.

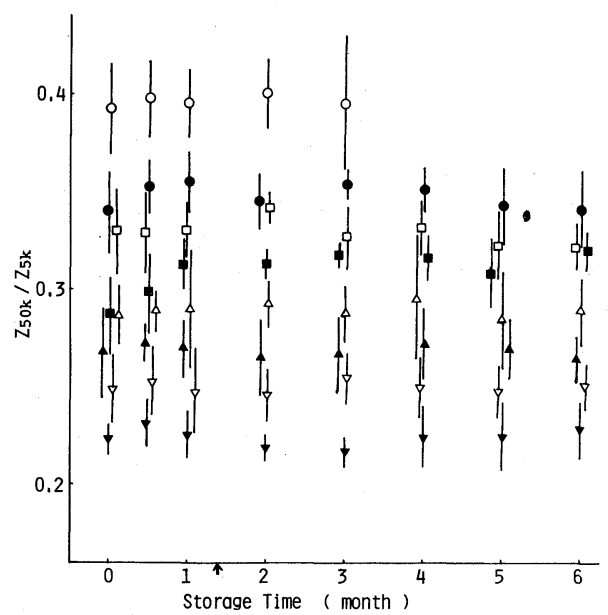

FIG. 13. Identification Parameter, $Z_{50 \mathrm{k}} / Z_{5 \mathrm{k}}$, for the Potatoes Stored at $15^{\circ} \mathrm{C}$.

$\bigcirc, 0 \mathrm{krad}$, $5 \mathrm{krad}$; $\square, 10 \mathrm{krad}$;, $15 \mathrm{krad} ; \triangle, 20 \mathrm{krad}$;

$\Delta, 30 \mathrm{krad} ; \nabla, 50 \mathrm{krad} ; \boldsymbol{\nabla}, 100 \mathrm{krad}$.

TABle III. Relationship BetWeEn IDENTIFICATION Parameters and IrRadiation Dose for Potatoes of Danshaku Variety

\begin{tabular}{cccc}
\hline & & Parameter & \\
\cline { 2 - 3 } Dose (krad) & $Z_{0} / Z_{180}$ & $Z_{50 \mathrm{k}} / Z_{0.5 \mathrm{k}}$ & $Z_{50 \mathrm{k}} / Z_{5 \mathrm{k}}$ \\
\hline 0 & $0.907 \pm 0.030$ & $0.298 \pm 0.025$ & $0.392 \pm 0.022$ \\
5 & $0.956 \pm 0.021$ & $0.260 \pm 0.021$ & $0.346 \pm 0.018$ \\
10 & $0.971 \pm 0.023$ & $0.247 \pm 0.017$ & $0.328 \pm 0.017$ \\
15 & $0.983 \pm 0.023$ & $0.229 \pm 0.021$ & $0.310 \pm 0.019$ \\
20 & $0.997 \pm 0.022$ & $0.209 \pm 0.023$ & $0.290 \pm 0.020$ \\
30 & $1.007 \pm 0.023$ & $0.182 \pm 0.030$ & $0.269 \pm 0.021$ \\
50 & $1.024 \pm 0.024$ & $0.158 \pm 0.025$ & $0.250 \pm 0.018$ \\
100 & $1.045 \pm 0.023$ & $0.129 \pm 0.026$ & $0.225 \pm 0.017$ \\
\hline$F$-Value & 450.0 & 778.6 & 1108.3 \\
$n$ & 1250 & 1250 & 1250 \\
\hline
\end{tabular}

ture and were valid up to 6th month after irradiation, the longest storage period tested.

It could be concluded that impedance measurement was a highly reliable and practical technique for the identification of irradiated potatoes, which facilitated not only the differentiation between unirradiated potatoes and irradiated ones but also the estimation of irradiation dose. Further study would be necessary to examine the applicability of the above criteria to potatoes other than Danshaku.
Acknowledgment. The authors wish to thank Mr. K. Kameyama at Shihoro Agricultural Co-operative who kindly provided potato samples of Danshaku, and Mr. N. Ishima in our Institute who gave useful advice on the statistical analysis of the data.

\section{REFERENCES}

1) FAO/IAEA/WHO Expert Committee, "Wholesomeness of Irradiated Food," Food and Agriculture Organization of the United Nations, Rome, 1977, p. 26.

2) FAO/IAEA/WHO Expert Committee, "Wholesomeness of Irradiated Food," World Health Or- 
ganization, Geneva, 1981, p. 31.

3) Japanese Research Association for Food Irradiation, Food Irradiation, Japan, 15, 70 (1980).

4) T. Hayashi, J. Fd. Sci. Technol., 26, 547 (1979).

5) H. Penner, "Colloquium on the Identification of Irradiated Foodstuffs, Luxembourg," Commission of the European Communities, Luxembourg, 1970, p. 67.

6) H. Penner, Z. Lebensm. Unters.-Forsch., 144, 99 (1970).

7) H. Penner, "International Colloquium. The Identification of Irradiated Foodstuffs, Karlsruhe," Commission of the European Communities, Luxembourg, 1974, p. 231.

8) H. Penner and F. Hartmut, Z. Lebensm. Unters.Forsch., 150, 84 (1972).

9) S. Shirsat and H. Penner, Z. Lebensm. Unters.Forsch., 151, 167 (1973).

10) H. Scherz, "Colloquium on the Identification of Irradiated Foodstuffs, Luxembourg," Commission of the European Communities, Luxembourg, 1970, p. 13.

11) H. Scherz, EUR4953, Euratom (1973).
12) H. Scherz, "International Colloquium, The Identification of Irradiated Foodstuffs, Karlsruhe," Commission of the European Communities, Luxembourg, 1974, p. 193.

13) R. V. Dongen, D. Onderdelinden and L. Strackee, "International Colloquium, The Identification of Irradiated Foodstuffs, Karlsruhe," Commission of the European Communities, Luxembourg, 1974, p. 203.

14) T. Hayashi and D. Ehlermann, Rept. Natl. Food Res. Inst., 36, 91 (1980); T. Hayashi and D. Ehlermann, Food Irradiation, Japan, 14, 28 (1979).

15) F. A. Blazich, D. R. Evert and D. E. Bee, J. Am. Soc. Hort. Sci., 99, 211 (1974).

16) C. V. de Plater and C. G. Greenham, Plant Physiol., 34, 661 (1959).

17) C. G. Greenham, K. Helms and W. J. Mueller, J. Exp. Botany, 29, 867 (1978).

18) G. M. Weaver, H. O. Jackson and F. D. Stroud, Can. J. Plant Sci., 48, 37 (1968).

19) C. G. Greenham, P. J. Randall and M. M. Ward, J. Exp. Botany, 23, 197 (1972). 